\title{
軟口蓋麻瘴の16例
}

\author{
豊田＼cjkstart健司・橘＼cjkstart正芳
}

\section{Sixteen Cases of Soft Palate Paralysis}

\author{
Kenji Toyoda and Masayoshi Tachibana \\ (Kyoto Prefectural University of Medicine)
}

We have treated 16 patients with soft palate paralysis, and present two cases here. One patient had a viral infection and the other myasthenia gravis.

Among the causes of soft palate paralysis, the incidence of diphtheria is decreasing, and viral infections and cerebrovascular disorders are most common.

Bilateral paralysis was noted in cases of amyotrophic lateral sclerosis and myasthenia gravis of the soft palate alone. When the paralysis is bilateral, diseases of the nervous system or hysteria should be suspected. In myasthenia gravis the antilex (Edrophonium) test is useful for diagnosis.

In all cases of viral infection, the paralysis was unilateral. In some cases other areas were also paralyzed. Four patients had laryngeal palsy, one had facial palsy, and one had accessory nerve palsy. These cases remind us that the soft palate receives nerve fibers from the nucleus ambiguus.

When viral infection is suspected the measurement of viral antibody titers is useful for diagnosis. In positive cases, we recommend $\gamma$-globulin or interferon as the intial therapy.

Key words : soft palate paralysis, viral infection, diphtheria, cerebral vascular disturbance, myasthenia gravis

\section{はじめに}

軟口蓋麻痺は，過去にはジフテリア後麻痖などを原因として多く認められ，さほど稀な疾患では なかった，しかし近年，ジフテリアの減少とともに本疾患も減少し，ともすれば等閉視されがちで ある. 我々の施設の最近 5 年間のカルテを検索したところ, 軟口蓋麻疾と診断された症例は 16 例で あった. これらの症例について若干の考察を加えここに報告する.

症

表 1 に今回経験した16例の一覧表を示す. 原 因の内訳は，脳血管障害 4 例，ウイルス感染に よると思われる咽頭炎等の感冒症状に続発した あの 7 例, 聴神経腫瘍術後発症したあの, 頸部
例

腫瘍の浸潤圧迫によるもの，重症筋無力症，筋 萎縮性側索硬化症によるものが，それぞれ 1 例 ずつであった。なお，ジフテリア後麻痺による あのは，1例もなかった：他汇原因となるもの 
がみあたらず，発症以前に咽頭炎等の感冒症状 がありウイルス抗体価の上昇をみたものはウイ ルス感染とした。 ウイルス抗体価は測定できて いないが，その疑いが強いものは疑問符を付け て示した.

図 1 亿年令分布を示す. 40才台をピークとし て中高齿者に多いことがうかがえる，男女比は 1.6：1 と男性にやや多いようである.

多くの軟口蓋麻舫は片側性であり左側と右側 の頻度には有意の差がなかった．両側性のもの は重症筋無力症, 筋萎縮性側索硬化症によるも のの各 1 例で，いずれあ神経・筋疾患であっ た。

ウイルス感染を疑い抗体価測定を行なった症
例では，単純ヘルペス，带状ヘルペス，ムンプ ス，パラインフルエンザ，コクサッキーA 9 。

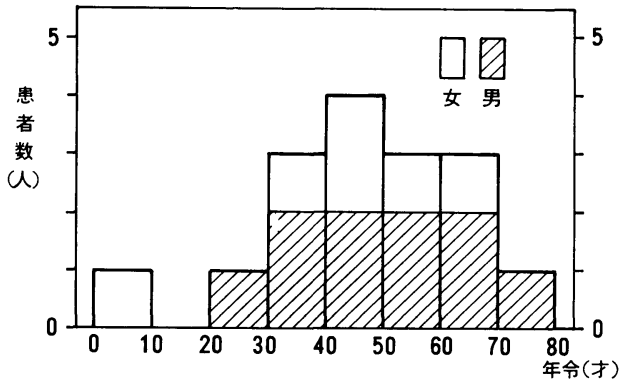

図 I 軟口蓋麻痷患者の年令分布 (京都府立医科大学耳鼻咽喉科学教室) （昭和55年～昭和59年）

表 I 軟口蓋麻舫患者の症例一覧表

（京都府立医科大学耳㸶喉科学教室 昭和 55 年 昭和 59 年）

\begin{tabular}{|c|c|c|c|c|c|c|c|c|}
\hline & 性 & 年令 & 噚症年月 & 訴 & 軟口蓋麻㾝 & 原 & ウイルス抗体価 & 合 併 麻 㾝 \\
\hline 1. & $\hat{\delta}$ & 24 & S. 55. 1月 & 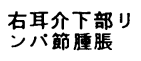 & 左 側 & ウイルス感染？ & & $(-)$ \\
\hline 2. & q & 49 & S. 55. 2月 & 咽頭異和感 & 左 側 & ウイルス感染？ & & $(-)$ \\
\hline 3. & $\hat{\delta}$ & 59 & 不 明 & 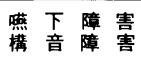 & 左 側 & 脳血管障害 & & $\begin{array}{l}\text { 上喉頭神経麻㾝 } \\
\text { (Avellis 症候群) }\end{array}$ \\
\hline 4. & & 2 & S. 55.10月 & 䫓面神経麻㾝 & 右 側 & ウイルス感染 & $\begin{array}{l}\text { 帯状ヘルル゚ス } \times 64 \\
\text { ムンプス } \\
\times 128\end{array}$ & 右㕹面面神経麻㾝 \\
\hline 5. & $\hat{\delta}$ & 60 & 不 明 & 顇面神経麻㾝 & 右 側 & 頸 部 腫 瘍 & & $\begin{array}{l}\text { 右顏面神経麻㾝 } \\
\text { 三叉神経麻㾝 }\end{array}$ \\
\hline 6. & of & 33 & 不 明 & 嗄 & 左 側 & 脳血管障害 & & $\begin{array}{l}\text { 左舌咽神経麻㾝 } \\
\text { 左迷走神経麻㾝 } \\
\text { 左副神経麻㾝 } \\
\text { (䣆静脈孔症候群) }\end{array}$ \\
\hline 7. & 古 & 72 & S. 56. 1月 & 嗄 & 右 側 & 脳血管障害 & & $\begin{array}{l}\text { 右喉頭麻㾝 } \\
\text { (Avellis 侯群) }\end{array}$ \\
\hline 8. & $\hat{\delta}$ & 45 & 不 明 & $\begin{array}{lll}\text { 嗄 } & \text { 声 } \\
\text { 頍 痛 }\end{array}$ & 左 側 & ウイルス感染？ & & 左喉頭不全麻㾝 \\
\hline 9. & ㅇ & 52 & S. 58. 5 月 & 声 & 右 側 & ウイルス感染 & $\begin{array}{llr}\text { 巣純ヘルベス } & \times 16, & \times 32 \\
\text { バラインルルンザ } \times 128, & \times 128\end{array}$ & $\begin{array}{l}\text { 両喉頭麻㾝 } \\
\text { ( Avellis 症候群) }\end{array}$ \\
\hline 10. & $\hat{\delta}$ & 47 & 不 明 & 開 声 & 両 側 & 重症筋無力症 & & $(-)$ \\
\hline 11. & $\delta$ & 33 & S.58. 5 月 & 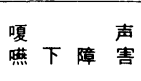 & 右 側 & ウイルス感染 & $\begin{array}{lll}\text { コクサッキーA } & 99 & \times 32 \\
\text { コクサッキーA } & 16 & \times 32 \\
\text { バラインフルッザ } & \times 128\end{array}$ & $\begin{array}{l}\text { 右唉頭麻㾝 } \\
\text { 右副神経麻㾝 } \\
\text { ( Schmidt 症候群) }\end{array}$ \\
\hline 12. & q & 44 & S. 58. 7月 & 嗄 & 右 側 & 聴神経腫瘍手術 & & $\begin{array}{l}\text { 石喉頭麻㾝 } \\
\text { 右頝面神経㾢 }\end{array}$ \\
\hline 13. & $\hat{\delta}$ & 51 & S.58.10月 & 呰下障害 & 右 側 & ウイルス感染 & 単純ヘルベス $\times 64$ & $\begin{array}{l}\text { 右喉頭麻㾝 } \\
\text { (Avellis 䧹候群) }\end{array}$ \\
\hline 14. & $\hat{\delta}$ & 62 & 不 明 & 左 難 聴 & 右 側 & 脳血管障害 & & $(-)$ \\
\hline 15. & q & 65 & 不 明 & 搆音障 害 & 両 側 & 筋萎縮性側索硬化症 & & $\begin{array}{l}\text { 両舌咽神経麻㾝 } \\
\text { 禹莒下神経麻㾝 }\end{array}$ \\
\hline 16. & $\hat{\delta}$ & 39 & S. 59. 8月 & 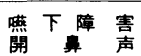 & 左 側 & ウイルス感染 & 単純ヘルベス $\times 16, \times 16$ & $(-)$ \\
\hline
\end{tabular}


A16型の抗体価上昇がみられ，あらかじめウイ ルス感染を疑っていた症例では全例に何らかの 抗体価上昇を認めた. ウイルス感染によると思 われるものにも, 喉頭麻痺等との合併麻舫がか なりみられた。

発症時期がはっきりしている症例はウイルス 感染による場合が圧倒的に多かったが，その季 節変動には大きな特徵はなかった。

次に16例の中から比較的詳細に経過を観察し 得た症例 9 及び症例10について報告する.

症例 $9: 52$ 才, 女性.

主 訴 : 嗄声.

家族歴：特記すべきことなし.

既往歴：昭和 47 年に慢性甲状腺炎乙診断され たが，そのまま経過観察中。

現病歴：昭和58年 5 月 4 日頃より险, 頭痛が 出現し感冒に罹患. 5 月 9 日夕より急に嗄声が 出現，翌日には呼吸困難も出現し，5月11日当 科を受診した。

現 症：軽度の呼吸困難が認められる。咽頭
粘膜は発赤し, 右軟口蓋は挙上不能である. 両 口蓋扁桃は特に異常ないが, 右声帯は正中位に 固定しており，左声帯にも軽度の運動障害が認 められる. ウイルス抗体価測定を 2 回施行して いるが, 単純ヘルペス・パラインフルエンザの 上昇が認められ前者は 2 回目の検査では更に上 昇していた。胸部レ線像，頭部 CTスキャンに は異常所見は認められなかった.

治療抢よび経過：症状の経過・治療等を図 2 に示した. 治療としては入院せしめ, 炎症の急 性期はすぎたと考えプレドニゾロン，ビタミン $\mathrm{B}$ 複合製剂を投与した。入院後 3 日目には軟口 蓋麻瘏が，19日目には左声带の運動障害屯消失 したが右声带の運動障害は結局回復しなかっ た.

症例10：47才，男性.

主 訴: 開鼻声。

家族歴, 既往歴 : 特記すべきととなし.

現病歴: 昭和 54 年 1 月頃, 突然開鼻声が出現 し, その後自然に回復した. 昭和58年 3 月中頃

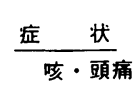

嗄声

呼吸困馑

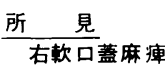

左声帯運動障害

右声帯運動障害

検査所見

白血球数 $\left(千 / \mathrm{mm}^{3}\right)$

ウイルス抗体価

単純ヘルペス $(\times 4)$

パラインフルエンザ $(\times 32)$

$\frac{\text { 治 療 }}{\text { ブレドニゾロン }(\mathrm{mg} / \text { 日 })}$

ビタミンB䙡合製剤( 3 錠/日)

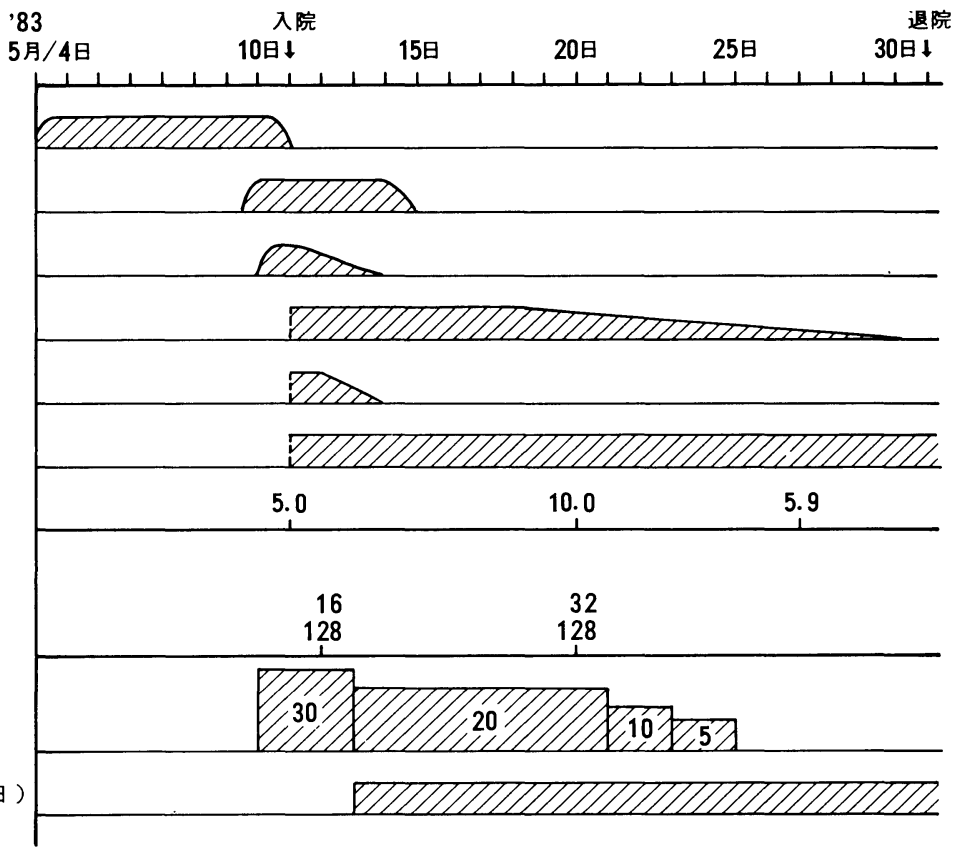

図 2 症例 9 の臨床経過 
より再び開鼻声が出現し, 水分曣下時鼻腔内逆 流む出現するようになったので 4 月 2 日当科を 受診した。

現 症: 两側軟口蓋麻痺が認められるが, 他 には鼻咽腔の異常所見は認められない. アンチ レックステスト（塩化ヒドロホニウム $10 \mathrm{mg} / \mathrm{ml}$ 静注前後の開鼻声度, 軟口蓋の動きをみる）を

考

軟口蓋麻痖は数十年前まではジフテリア後麻 瘏として数多く報告され(1) 4), 全麻瘏例の $85 \%$ 近くを占めていた。ジフテリアが減少した現 在, 軟口蓋麻痺は今回の結果などから, ウイル ス感染，脳血管障害によるものが主流をなすと 考えられる。乙れらのととを考虑したうえで軟 口蓋麻盘の原因を中村・水越 ${ }^{2)}$ による分類を参 考に表 2 の如く再分類してみた。 感冒症状等が ありウイルス感染が疑われた場合には，ウイル
施行したところ，開鼻声及び軟口蓋の動きの改 善がみられた。

治療及び経過：以上より重症筋無力症の軟口 蓋限局型と考え，臭化ピリドスチグミン $120 \mathrm{mg}$ /日，メコバラミン $1,500 \mu \mathrm{g} /$ 日を内服投与した ところ症状の改善が認められ現在経過観察中で ある.

\section{按}

ス抗体価の測定が有用であった。ペア血清のウ イルス抗体価測定が理想ではあるが今回の我々 の症例では全て初診時には抗体価上昇が認めら れ，1回の検査でもある程度の類推はできよ う.

両側軟口蓋麻瘏を認めたものは今回の15例の 中では重症筋無力症・筋萎縮性側索硬化症によ る 2 例であり, ウイルス感染によるむのは疑い 例を含め全て片側性であり，過去の文献におい

表 2 軟口蓋麻㾝の原因

\begin{tabular}{|c|c|}
\hline A. 末梢 性麻㾴 & B. 中枢性麻㾝 \\
\hline 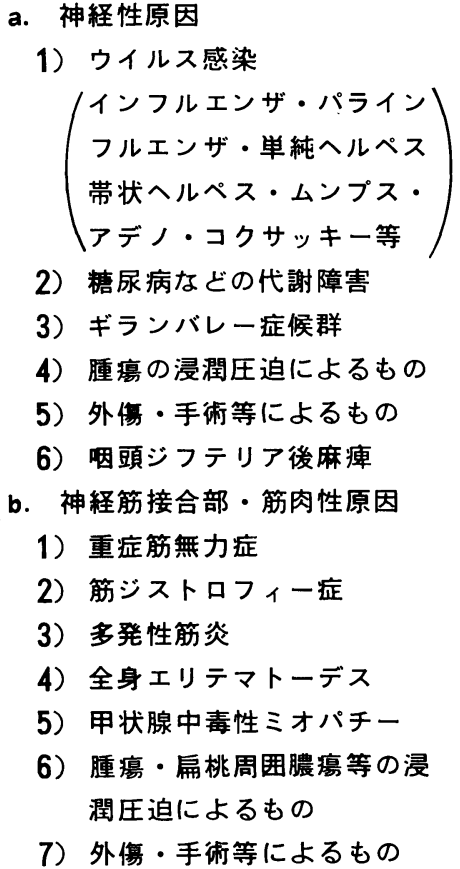 & 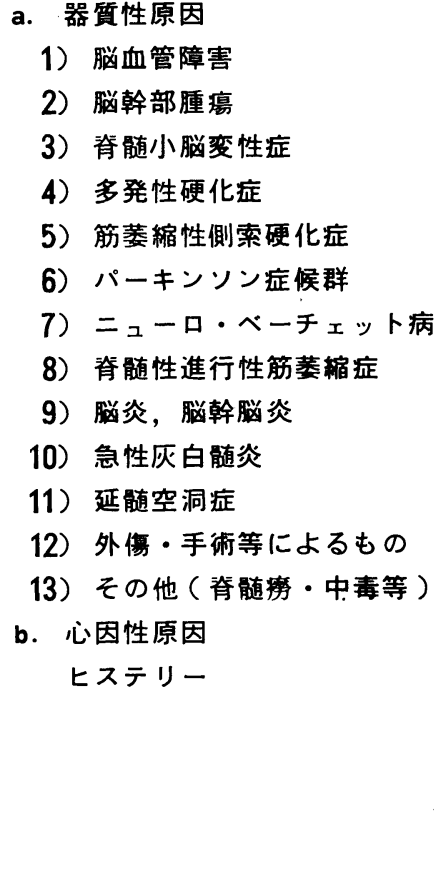 \\
\hline
\end{tabular}


ても両側性麻舫はジフテリア後麻瘏及び重症筋 無力症による症例が報告されている ${ }^{1) \sim 4)}$ のみ

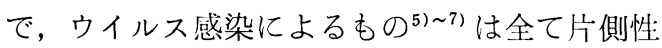
であった．筋萎縮性側索硬化症においては延䯑道 球麻瘏の一部としてみられ, 他に舌の萎縮, 筋 繊維束攣縮を伴う為これを鑑別することはさ程 困難ではない. しかし，重症筋無力症において は今回の症例のように，軟口蓋にのみ限局して 発症することがあり，闫側軟口蓋麻瘏を認めた 場合には舌の動き等, 他の神経症状を調べるこ とは勿論のとと重症筋無力症も念頭において診 ることが必要であり, この際アンチレックステ ストはその診断に非常に有用な手段であった。

軟口蓋の運動に関与する筋は口蓋帆挙筋であ り，口蓋帆張筋は関与していないと本庄ら ${ }^{8)}$ は 報告している. 口蓋帆挙筋の支配神経について は，平野9)は逆行性軸索内輸送を利用し軟口蓋 に H R P (Horse-Radisch Peroxidase) を注 人し，中枢での鳔識細胞を調べている，その結 果標識細胞は疑核のほぼ中央 $1 / 3$ のレベル内に 認められ，下オリーブ核の発達した高さのやや 吻側よりから舌下神経核の吻側部のわずか尾側 の高さにまで細胞柱は延び，横断面内の局在は 核のほぼ中央部を占めるとしている。乙れにつ いては，逆行性変性法により Lawn $ら^{1011)}$ 口蓋帆挙筋の運動性ニューロンは疑核の中央部 にあると報告している。しかし，顔面神経麻脾 に伴なって軟口㥺麻㯅がみられた症例から顔面 神経を支配神経とする報告 ${ }^{12 \sim 14)}$ あある。 今回 の我々の症例に打いてウイルス感染が原因之考 えられる軟口蓋麻痺の 8 例中， 1 例にのみ顔面 神経麻痺の合併が認められた。この症例におい ては带状ヘルペスの抗体価.上昇が認められハン
卜症候群之考えられるが, 他の 7 例には何ら顔 面神経支配領域の異常が認められず，喉頭麻瘦 を合併するものが半数近くを占めていた．従っ て軟口莣は, やはり迷走神経疑核支配と考える と理解しやすい。

軟口蓋麻瘏患者が訴える主な症状としては開 鼻声, 飲食物の鼻腔への逆流, 咽頭腔への鼻汁 の漏出, 咽頭異和感, 曣下障害等があるがこれ らの症状を何ら訴えない場合も多いとされ，今 回の症例においても嗄声や顔面神経麻瘏を主訴 として受診した患者が 15 人中 7 人と, 約半数を 占めていた. このてとからも患者の症状の有無 や種類にかかわらず, 軟口蓋の運動についても 十分な注意をむって診る様に習慣づけることが 必要であると再認識した。

軟口蓋麻瘏に対する治療としては, 急性期に は, ビタミン $\mathrm{B}_{1} \cdot \mathrm{C}$ の大量投与, 副腎皮質ホル モン投与, 生食水の局所注射 ${ }^{15)}$, 臭化ピリドス チグミン投与, 軟口蓋のマッサージあるいは温 熱制激療法等が報告されており，乙れに対して 慢性症例では咽頭弁形成術を行ない奏効をみた とする報告3)16)17) がある．乙れらの治療法の内 には今日なお有意義と考えられるものも多い が, 現在のように原因追求がかなり出来る様に なった以上，やはり原因に応じた治療をまず試 みる心゙きであろう。例えば今回多くみられたウ イルス感染によるものでは早期に確診をつけ， r-グロブリン製剂，インターフェロン等による 積極的な抗ウイルス治療を試み, 次いで副腎皮 質ホルモン投与等により麻痺改善の策をとるの が理にかなっているかと思われる. 今後の指針 としたい.

\section{ま と め}

1）過去 5 年間に軟口蓋麻瘏を認めた 16 例について考祭を加えその中からウイルス感染によると 考えられるもの及び重症筋無力症にするもの，2 例を紹介した.

2 ）ジフテリアによる軟口蓋麻瘏が減少した現在, ウイルス感染, 脸血管障害によるものが原因 の大部分を占めることが判明した，とのととを考虑し軟口蓋麻瘏の原因を新しく分類してみた（表 2 ). 
3 ）ウイルス感染を疑い抗体価测定を行なった症例では全例に何らかの抗体価上昇を認め，ウイ ルス抗体価測定は有用であった。 今後は $\gamma$-グロブリン製剂，インターフェロン等の皘極的な原因 疾患の治療屯必要ではないかと考える.

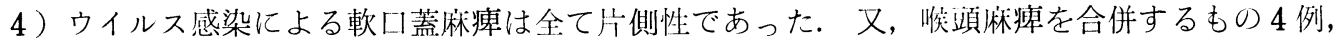
顔面神経麻㾝・副神経麻疾を合併するもの 1 例であった。このととは軟口蓋の運動神経が疑核支配 と考えると理解しやすいと思われた。

5 ) 両側性の軟口蓋杪痺を認めたものは，筋萎縮性側索硬化症及び軟口蓋限局性の重症筋無力症 であった。ジフテリア後麻盘のほとんどみられなくなった今日，両側性の場合にはこれら神経・筋 疾患及びヒステリ一をまず念頭におく必要があると思わ机る。なお重症筋無力症ではアンチレック ステストが診断に有用な手段であった。

稿を終るにあたり，御校閲を賜った恩師水越 治教授に深甚なる謝意を表します。本論文の要旨は第26回日本 耳鼻咽喉科学会京滋合同地方部会で発表した。

\section{參 考 献}

1) 手塚 正：ヂフテリ一後麻脾（軟口蓋）に対する 頸動脈注射による 1 治験例. 耳喉 $22: 71 \sim 72$, 1950.

2 ）中村文雄, 水越 治：軟口蓋麻猩. 耳喉 $24: 66$ $\sim 69,1952$.

3) 田縁 昭, 涉谷证機, 児玉国明: 後天性口蓋機能 不全症の一例. 九雬会誌 $22: 304 \sim 309,1969$.

4 ) 丸岡修三，小林茂子：ジフテリア後麻瘏の一重篤 症例. 耳喉 $34: 1055 \sim 1058,1962$.

5 ) 加藤良策, 志多 享：軟口蓋麻癘の 1 症例と其の 原因的考察. 耳喉 $27: 363 \sim 365,1955$.

6 ) 㿢野 宁, 田中康夫, 内田一男, 方円正久：軟口 蓋麻脾の 2 症例. 耳喉 $31: 483 \sim 485,1959$.

7 ) Nussey AM: Paralysis of palate in a child. British Medical J I6: 165 166, 1977.

8 ) 本庄 簏, 岡崎伸博, 野添恒幹, 浜崎浜子: 口蓋 運動における口蓋帆張筋機能の再検討. 日耳鼻 82 : 1495 1501, 1979.

9 ) 平野 実: 呼吸・鮕下. 発声の制御. 篠原出版, 東京, 1982 .

10) Lawn AM : The nucleus ambiguus of the rabbit. J comp Neurol 127:307 320, 1966.

11) Lapresle J and Annabi A : Olivopontocerebellar atrophy with velopharyngolaryngeal paralysis: A contribution to the somato- topy of the nucleus ambiguus. J Neuropathol Exp Neurol $38: 401 \sim 406,1979$.

12）坂田 正：非ヂフテリア性軟口蓋麻奍について。 耳喉 $24: 180 \sim 182,1952$.

13) Seinsch $W$ and Schussler U : Zur Differentialdiagnose der Gaumensegelparesen.

Laryng Rhinol Otol 6I : 182 183, 1982.

14) Moritz W : Über die Funktion und Innervation der Muskulatur des weichen Gau mens. Z Anat Entwickl Gesch 109:147, 1939.

15）青村瑤子, 阿部敏子, 板井節子, 井上久子：妊婦 にみられたる口蓋帆麻瘏症例. 耳喉 21：356〜 357,1949

16）田縁 昭, 上西創造，塚本 博，丸田輝彦：口蓋 咽頭弁移植法を行った口蓋運動麻痖患者例につい て. 九菌会誌 $21 ： 286 \sim 287,1967$.

17）田縁 昭, 堤 直文, 緒方義昌, 柿原康男：口盍 機能不全に対する Pharyngeal flap operation とその効果に関する 研究. 九曾会誌 $24: 811$ $820,1971$.

原稿到着：昭和60年 3 月 25 日

別刷請求先：豊田健司

干620京都市上京区河原町通広小路上儿梶井町465 京都府立医科大学耳鼻咽喉科学教室 